\title{
Analysis of questionnaires surveys and overviews on the gaps of past research causing plant disease and people health hazards in the Sundarbans
}

\author{
Awal, Mohd Abdul \\ Environmental Scientist (Ministry of Environment \& Forest), and Founder \& Chief Advisor, Health \& Pollution Research Farm, \\ Bangladesh, 23-09-37 Avenue, Apt, No: 1, Long Island City, New York, USA \\ Email address: \\ abdul_awal2004@yahoo.com
}

\section{To cite this article:}

Awal, Mohd Abdul. Analysis of Questionnaires Surveys and Overviews On the Gaps of Past Research Causing Plant Disease and People Health Hazards in the Sundarbans. American Journal of Life Sciences. Vol. 2, No. 3, 2014, pp. 155-163.

doi: 10.11648/j.ajls.20140203.15

\begin{abstract}
Coastal belts render energy \& operative support to people and natural resources (Awal, M.A.2007). But the Sundarbans is being contaminated by various environmental factors such as heavy metal contaminations in soil and water as well as people health (Awal, M.A. 2014). So, a questionnaire survey was conducted among different groups of people inside and outside of Sundarbans to explore local perceptions as to the possible causes of disease of plants in Sundarbans (Awal, M.A.2009). This confirmed the increase in top-dying prevalence. Despite various hypotheses as to the causes of this top-dying, the underlying causes are still not well understood. The present work has explored some of the possible factors involved, focussing particularly on the relationship among the amount of top-dying in different places and the human destruction of Sundarbans ecosystem as well as abnormal concentrations of a number of chemical elements present in the soil, in order to test the hypothesis that ecological pollution, along with chemical pollution might be responsible. Of the hypotheses previously put forward to explain top-dying, the present results do not support enhanced salinity as the cause. It is likely that several of the above-mentioned environmental factors interact with each other to induce top dying in Sundri (Awal, M.A. 2004). However, the present results have showed that Sn, Exchangeable K, soil pH, Pb, Zn and Ni could be directly linked with top-dying disease of Heritiera fomes (Sundri) in Sundarbans, probably particularly by weakening the vigour of the trees and people and allowing other factors such as pathological agents to attack the plants and surrounding people in Sundarbans, Bangladesh (Awal, 2014).
\end{abstract}

Keywords: Environmental-Factors, Environmental Pollution, Heritiera Fomes, Mangrove, Sundarbans, Status of Human Health Hazards in Sundarbans, Top-Dying, Site Quality, Disease of Plants \& Surrounding People

\section{Introduction}

Due to over-felling, principally of Sundri and Excoecaria agallocha (Gewa) for timber and industrial raw materials, the overall loss of mangroves area in Bangladesh had exceeded 300,000 cubic meters annually (FAO, 1982). The Chakoria Sundarban in eastern Bangladesh, which has now been almost completely depleted for aquaculture (ADB, 1995), cleared by 34\% between 1975 and 1990-91, and in Sundarbans the amount of Heritiera fomes(Sundri), declined from 31.6 to $21.0 \%$ of the total number of trees between 1959 and 1983 (Chaffey, 1985). Thailand's mangrove forests, where more than half of the total area (some 208220 ha) was lost, and Bangladesh's Chakoria Sundarban mentioned above which disappeared between 1961 and 1993, are two notable examples of such mangrove forest decline.

Land reclamation and other coastal developments have also been responsible for the destruction of wildlife habitats and natural resources, as well as some fine natural coastlines in the Republic of Korea (Government of Republic of Korea, 1994). The total management resource in Thailand has shrunk from an estimated 368,100 ha in 1961 to 196,643 ha in 1986-87 (FAO, 1982). Such mangrove areas are under various threats from humanintensification, disturbance and exploitation. In respect of 
non-wood forest products, the importance of bark tannins has declined in many Asian countries, but some mangrove tannin is still used in India and Bangladesh for leather curing and for fishing-nets curing in Sri-Lanka (FAO, 1982) through deforestation (Awal, 2007). Deforestation and its offset on natural cycles cause is in fact our overbearing species. Man has so dominated the natural systems of the world (The American GeophysicalUnion, 2014) such as ongoing-deforestation is a primary concern in creating liable, comfortable neighbourhoods for communitybuilding (Awal, 2014). Deforestation causes also global warming Key role for developing countries in fighting greenhouse gas emissions 4 September 2006, Rome - Most people assume that global warming is caused by burning oil and gas. But in fact between 25 and 30 percent of the greenhouse gases released into the atmosphere each year1.6 billion tones - is caused by deforestation (UN, 2006).

Trees are 50 percent carbon. When they are felled or burned, the $\mathrm{C} 02$ they store escapes back into the air. According to FAO figures, some 13 million ha of forests worldwide are lost every year (UN, 2006), almost entirely in the tropics (FAO, 2006). Deforestation remains high in Africa, Latin America and Southeast Asia (UN, 2006). In South America, mangrove forests extend from northern Peru on the pacific coast and from Brazil's southern state of Rio Grande do Sul on the Atlantic coast. The mangroves of the Americas continue north along both sides of the
Central American isthmus. The 3,900 km Pacific coast had over 340,000 ha of mangrove forests, with a higher floristic diversity than the Caribbean community (Jimenez, 1985). Aridity and the cold Humbolt current limit the southern extension on the Pacific side to about 6 degrees south, whereas higher rainfall and warm currents along the southern coast of Brazil permit mangrove growth to about 28 degrees south. Explanation of mangroves is extensive in this reason too. In Honduras, between 80,000 and 120,000 cubic meters of mangrove are estimated to be used for firewood annually. In Nicaragua, according to the permits granted, 9,000 cubic meters a year are collected for firewood (Jimenez, et al., 1985), and according to the researchers, the El Salvador harvest is approximately 30,000 cubic metres a year (Miranda, 1998). Buffington (1987) reported that California had lost $91 \%$ of its wetlands, the Louisiana delta had been losing $104 \mathrm{~km}^{2}$ each year recently prior to that date and the national loss rate for wetlands in the $1970 \mathrm{~s}$ was 185,000 hectares a year (Tiner, 1984).

\subsection{Location}

The Sundarban mangrove forest is located mainly at the southern portion of the Gangetic delta bordering on the Bay of Bengal of Bangladesh (Awal, 2007, Blasco, 1977; Naskar 1999; and Bakshi, 1954; Thom, 1982, Figure1.1).

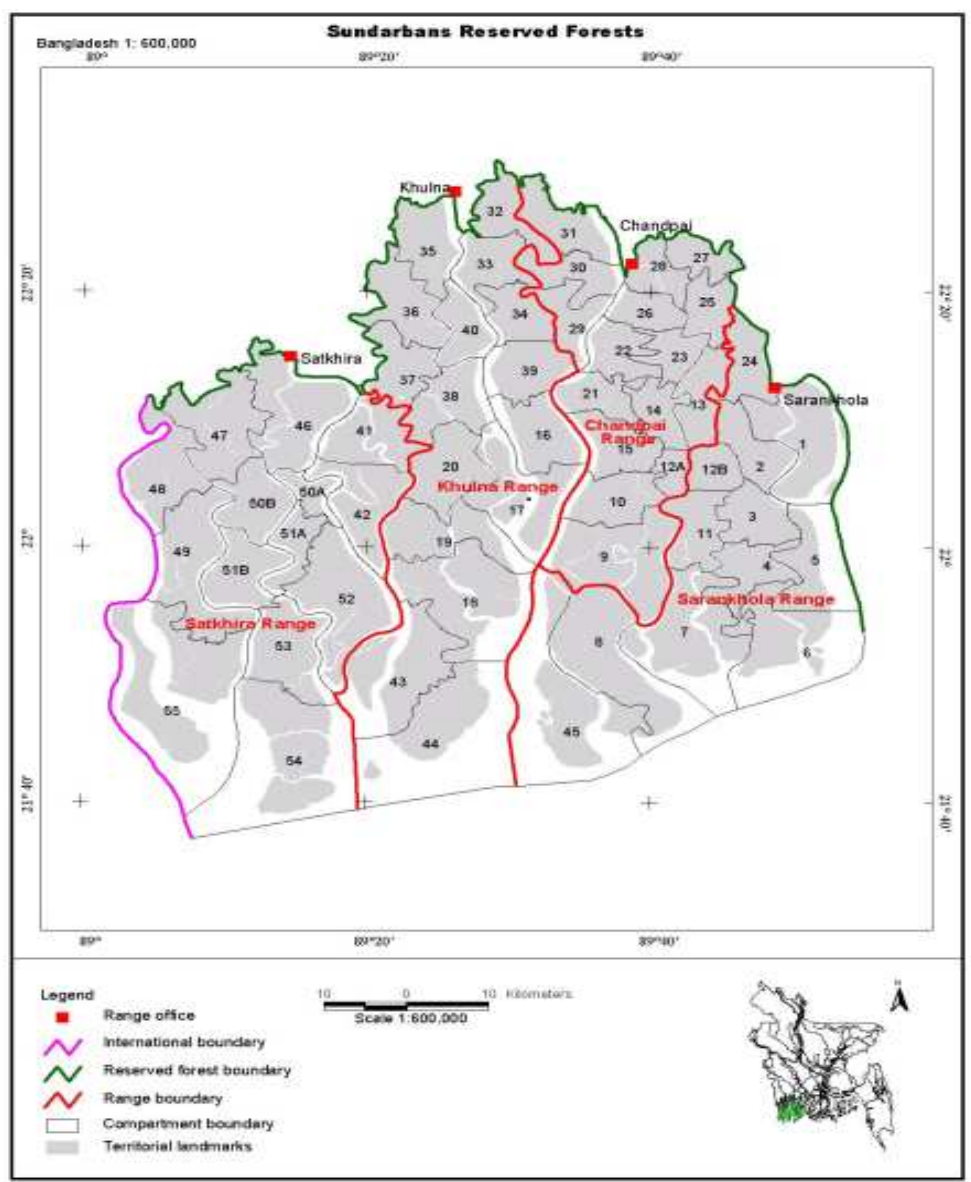

Figure 1.1. Shows compartment numbers and Ranges of Sundarbans Reserved Forest. 
It occupies a flat deltaic swamp rarely exceeding 0.9 to $2.1 \mathrm{~m}$ above the sea level and most of the area is under water during the high spring tides of the monsoon and the major portion of land is a low plain with maximum $10 \mathrm{~m}$ height above mean sea level (FAO, 1994). Sundarbans is subdivided into 8 blocks (Rahman, 2003) and further subdivided into 55 compartments (Figure 1.1), varying in size from 4000-16,000 ha (Tamang, 1993), depending on the height classes \& stocking conditions of the forest trees. The forest lies just south of the topic between $21^{\circ} 38^{\prime}$ $22^{\circ} 30^{\prime}$ North latitudes and $89^{\circ} 0^{\prime}-90^{\circ} 0^{\prime}$ East longitudes. Within the total areas of the Sundarbans, Heritiera fomes constituted $63.8 \%$ among the total tree vegetation (Chaffey et al., 1985).

\section{Methodology}

In order to establish the views of local people about the incidence and causes of top-dying, people health status in Sundarbans, a questionnaire was prepared for asking peoples either individually or in groups. This survey was done among people living or working in the 17 SubDistricts of Sundarbans, making a distinction between those living within and outside of Sundarbans. They were asked whether they had seen the top-dying disease of Heritiera fomes (Sundri) and people health's problems in Sudarbans for a long time, either through living within the Sundarbans or through visiting Sundarbans for their daily work, researchers, students, for their professional works such as forestry officials, for fishing or for collecting wood as wood cutters, for seasonal Goran (cyriops decandra), Goal-pata (Nypa fruticans), honey collections, or other purposes. Groups were made up among targeted people in all locations and from all categories mentioned above, based on age, profession, and also for their sharp memory. In this way, 50 questionnaires were filled up through interview, mostly of groups and sometimes of individual people. The justification of selection of people for the questionnaire survey was that the targeted people were familiar with the top-dying disease \& people health's problems in Sundarbans, and are related through their professions with Sundarbans directly and indirectly. The questionnaire started by establishing that the respondents were familiar with top-dying, people health, changes of soil and water criteria, and went on to seek their views and information on what changes they had observed and whether they had noticed possible causes. This was possible because, most of the interviewees are living within the Sundarbans for their daily activities.

So, this survey was performed to receive their original, indigenous, and self-motivated, as well as prudent response and knowledge towards top dying and its present conditions and health status of surrounding people in Sundarbans, and soil, water, flora and fauna condition as well as their original and baseline-ideas about what leads to top-dying, as well as questions about tree regeneration and human health hazards and other environmental problems in Sundarbans, Bangladesh. The questions asked are shown in Table 2.1.

Table 2.1. Questionnaire on top-dying in Sundarbans for neighbouring and related people.

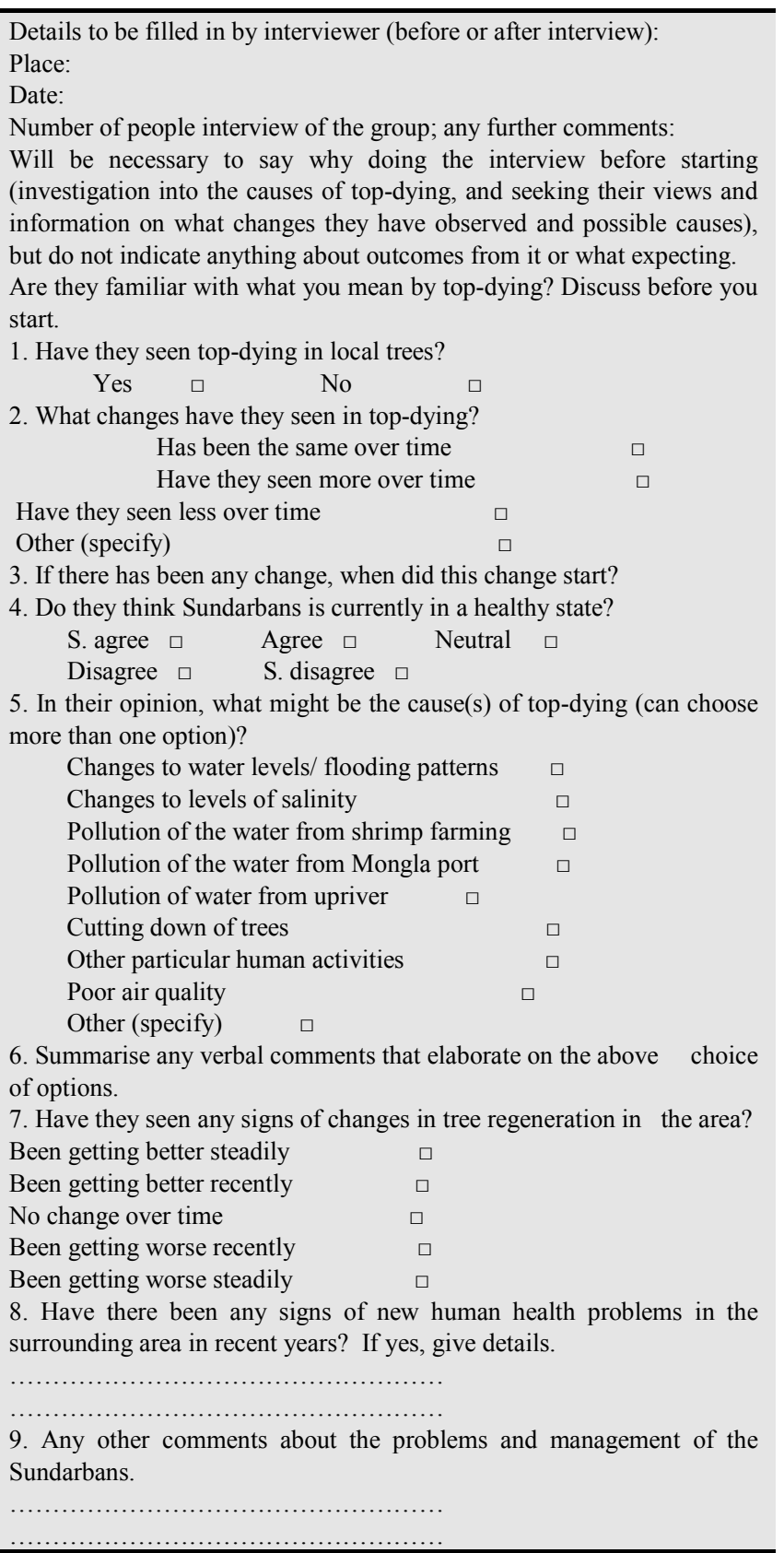

\section{Result}

Many of the sessions interviewing local people were conducted as part of groups, although some, particularly of the professional people who work in the Sundarbans, were interviewed individually. Consequently, a total of 50 questionnaire forms were completed, although this represented the comments of people. The responses to the various questions are summarised in turn below, with one 
response per questionnaire whether it came out of a group decision either individually or in behalf of organization and Institution. Each and every interviewee had seen top-dying and people health's problems and other most relevant environmental factors causing environmental pollutions and chemical contamination (Awal, 2014) in Sundarbans areas before, and they had all observed changes in the Sundarbans (Awal, 2014), including top-dying, soil erosion and siltation as well as people health \& epigenetic problems within the study areas (Awal,2009).

\section{Changes in Top-Dying Over Time}

Out of 50 responses, 49 answered that top dying disease of Sundri has increased at an increasing rate over time in Sundarbans (Figure 3.1).

This near unanimity provides clear evidence that the problem is getting very noticeably worse over time. The majority of respondents did not know when observed changes of ecosystem destruction of Sundarbans started. The largest number of responses indicating a particular date focussed on 1971, which corresponded to the war of Bangladesh liberation period and the creation of the state of Bangladesh.

A number of responses focussed on much earlier dates; 1933, or the beginning of human influences; and there was a selection of other dates suggested. It is clear that there is no obvious starting point for the deterioration of the condition of the trees in the Sundarbans (Awal, 2007).

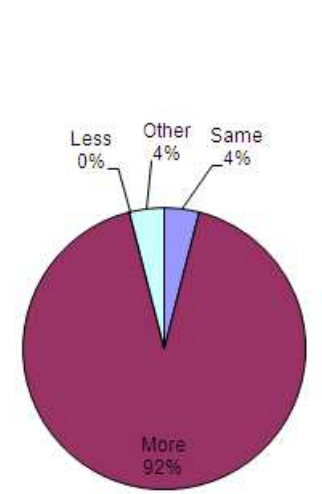

\begin{tabular}{|l|}
\hline 口Same \\
aMore \\
aLess \\
aOther \\
\hline
\end{tabular}

Figure 3.1. Responses to question 2 about the changes observed in topdying over time.

This might be because it was not noticed; because it did not start obviously at any particular time but became gradually worse; because it pre-dated when the respondents were alive or working in the area; or it could be that different parts of Sundarbans have been affected at different times. The fact that most respondents did not know when it started suggests that it was not an obvious and abrupt change, but more likely a very gradual one.

\section{The Timing of the Start of the Changes Observed}

As a follow-up to the question of whether there had been any changes, this question explored when any such changes began. The responses are summarised in Table 3.1.
Table 3.1. Responses to question 3 about when any observed changes started.

\begin{tabular}{ll}
\hline Since when & Frequency \\
\hline Beginning of human influences. & 3 \\
1933 & 3 \\
1955 & 1 \\
1960 & 1 \\
1970 & 1 \\
1971 (Liberation war) & 4 \\
1975 & 2 \\
1980 s & 1 \\
Last c.20 years & 2 \\
Unknown & 10 \\
\hline
\end{tabular}

The current state of the Sundarbans: When asked whether they thought the Sundarbans was currently in a healthy state, two agreed but all the others either disagreed or strongly disagreed (Figure 3.2).

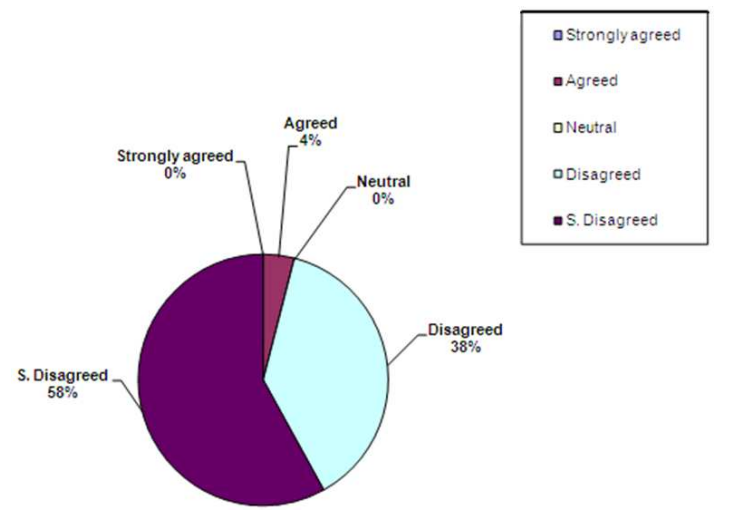

Figure 3.2. Responses to question 4, whether the interviewees thought Sundarbans is currently in a healthy state.

\section{Suggested Causes of Top-Dying}

The fifth question indicated various possible causes of top-dying and asked respondents to state which they considered to be responsible for the observed top-dying. It was possible to choose more than one option, and alternative causes not indicated could be included through the 'other' option.

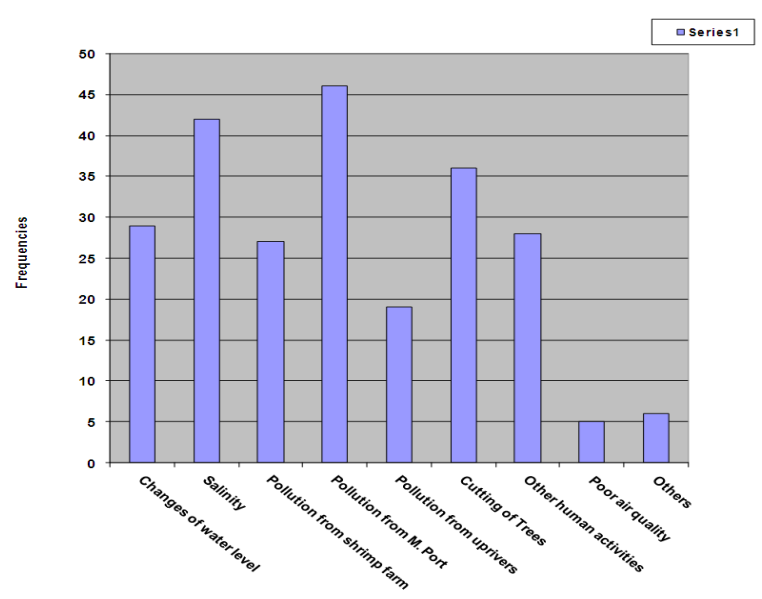

Figure 3.3. Causes of top-dying, as suggested by questionnaire respondants. 
The frequency of responses is indicated in Figure 3.3. According to the respondants, the most likely cause of topdying was from pollution of the water from the Mongla port. The next highest possibility was from changes to levels of salinity, followed by the cutting down of trees and deforestation in Sundarbans. However, all of the possible options were selected a number of times, including the 'other' category. Therefore, it is not possible to pick out one cause as being indicated overwhelmingly by the respondents.

\section{Further Comments Provided by Respondents}

The interviewees were asked to provide any further comments about the top-dying observed and its causes.

Table 3.2. Summary of the further comments provided in response to question 6 of the questionnaire.

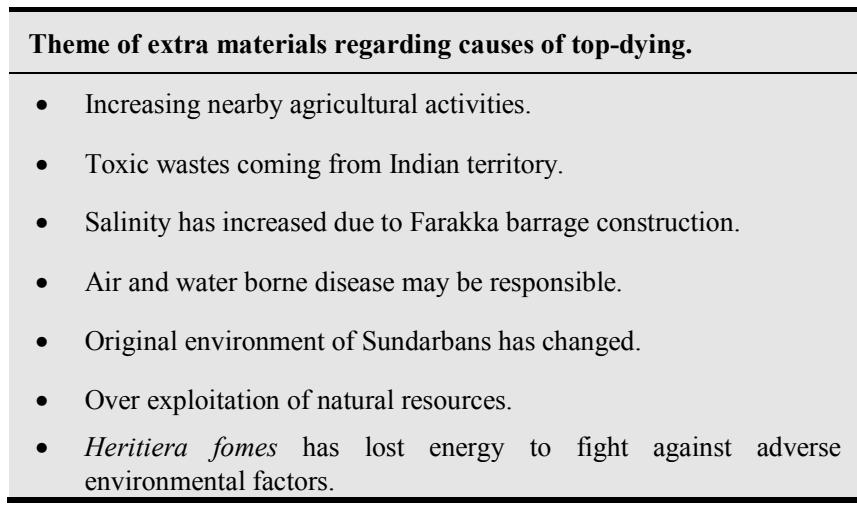

In many instances, these comments were reinforcing the opinions summarised in Figure 3.3 regarding the possible causes of the top-dying, and are not listed here. However, some of the comments provided further information which might be relevant, and these are summarised in Table 3.2 above. A number of people said that they did not know what the actual causes of top-dying were, but the main themes highlighted were environmental pollution, creation of God which had been destroyed by human destruction, and restriction of fresh water flow in Sundarbans, Bangladesh.

\section{Changes in the Tree Regeneration in Sundarbans}

In response to question 7, which asked whether there had been any observable changes to tree regeneration in the Sundarbans, a small number of respondents thought that regeneration had improved, one thought there had been no change, but most people considered regeneration to have become worse, either recently or steadily over time (Figure 3.4). This pattern of responses is consistent with those shown in Figure 3.2 regarding the current health status of the Sundarbans.

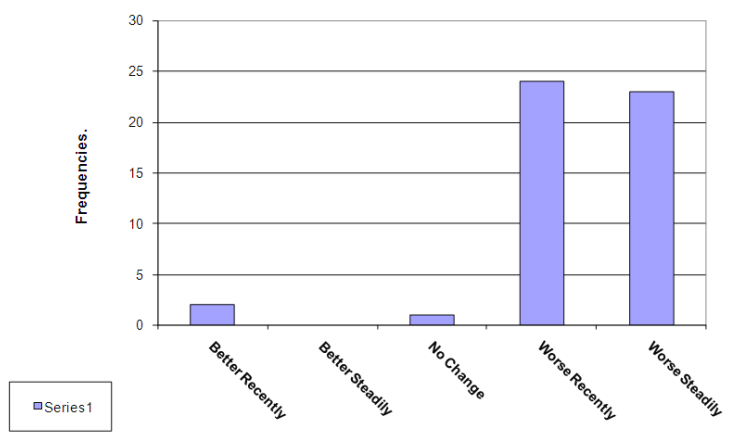

Fig 3.4. Comments on changes in tree regeneration in Sundarbans in response to question 7 .

\section{Evidence of New Health Problems of People Living in or around the Sundarbans}

As well as seeking evidence about the health status of the Sundarbans, the questionnaire attempted to assess whether there were increasing health issues for the local people resident in the area of Sundarbans.

The responses to question 8 were varied, but an analysis of separate themes raised is included in Table 3.3, in which the number of questionnaires mentioning that theme is indicated. It should be noted that one response could include more than one theme. According to the below table, people thought that several human health problems are present among the neighbouring peoples of Sundarbans areas. These included particularly skin irritation, black spots on organs of their bodies such as hands and on arms, as well as spots on their faces, dysentery and diarrhoea, and cholera problems. They thought that excessive abnormal concentrations of metals mainly with Lead $(\mathrm{Pb})$, Nickel (Ni), Zinc (Zn), Arsenic, Mercury (Hg) and other harmful heavy metals in soil and water, food, air, flora and fauna being particularly mentioned and also excessive salinity, were responsible for these diseases (Awal,2014).

Table 3.3. Summary of the health issues raised by respondants associated with the Sundarbans.

\begin{tabular}{|c|c|}
\hline Health issues raised & $\begin{array}{l}\text { Number of times } \\
\text { raised }\end{array}$ \\
\hline - $\quad$ Arsenic problems. & 2 \\
\hline - $\quad$ Ground water problem. & 1 \\
\hline - $\quad$ Skin complaints (irritation or dark spots). & 16 \\
\hline - $\quad$ Allergy problems. & 2 \\
\hline - $\quad$ Diarrhoea. & 6 \\
\hline - $\quad$ Dysentery. & 2 \\
\hline - $\quad$ Fevers. & 3 \\
\hline - $\quad$ Stomach complaints. & 2 \\
\hline - $\quad$ Cholera. & 2 \\
\hline - $\quad$ Eye problems. & 1 \\
\hline - $\quad$ Hair greying. & 1 \\
\hline - $\quad$ No idea / unknown. & 28 \\
\hline - $\quad$ Other new diseases (unspecified) & 1 \\
\hline
\end{tabular}




\section{Suggestions from Local People about the Better Management of Sundarbans in Bangladesh}

Table 3.4. Responses to the question 9 about the management and conservation of Sundarbans in future.

\begin{tabular}{|c|c|}
\hline Recommendation. & $\begin{array}{l}\text { Frequency theme } \\
\text { was raised. }\end{array}$ \\
\hline Scientific management is needed. & 7 \\
\hline - $\quad$ Siltation management required. & 1 \\
\hline $\begin{array}{l}\text { - Needs undisturbed management by local } \\
\text { people. }\end{array}$ & 1 \\
\hline - $\quad$ Proper environmental management needed & 15 \\
\hline $\begin{array}{l}\text { - Needs undisturbed environmental } \\
\text { management. }\end{array}$ & 5 \\
\hline $\begin{array}{l}\text { Management suited to a tropic } \\
\text { environment required. }\end{array}$ & 1 \\
\hline - $\quad$ Laboratory scale study is required. & 1 \\
\hline $\begin{array}{l}\text { - Sincerity, honesty and hard work of all } \\
\text { forestry staff essential. }\end{array}$ & 2 \\
\hline $\begin{array}{l}\text { All kinds of human destruction needs to be } \\
\text { banned. }\end{array}$ & 2 \\
\hline $\begin{array}{l}\text { - No deforestation, tree-cutting, clearing, } \\
\text { burning, poaching etc. allowed. }\end{array}$ & 2 \\
\hline - No human disturbances should be allowed. & 5 \\
\hline $\begin{array}{l}\text { - Tree cutting and deforestation must be } \\
\text { stopped for } 30 \text { years. }\end{array}$ & 1 \\
\hline - Quality research is needed. & 7 \\
\hline - Identify real causes of top-dying. & 1 \\
\hline - $\quad$ Education of people needed. & 1 \\
\hline - $\quad$ Sustainable use of resources required. & 5 \\
\hline $\begin{array}{l}\text { - Collaboration and cooperation between } \\
\text { officials needed. }\end{array}$ & 1 \\
\hline - $\quad$ Age of forests needs to be verified. & 1 \\
\hline - $\quad$ None. & 3 \\
\hline
\end{tabular}

The respondants provided various recommendations for the better management of the Bangladesh Sundarbans. These recommendations are summarised in Table 3.4 below. In many respects the comments summarised in Table 3.4 represent something of a 'wish list' with rather imprecise objectives, although there are a few more specific recommendations such as the ban on tree cutting (legal and illegal) for 30 years advocated by one respondent. However, it is clear that most of the replies emphasise that appropriate (with adjectives including 'proper', 'scientific', 'modern' 'or 'sustainable') management be employed to protect the Sundarbans; that this is often thought to require lack of disturbances, possibly banning or restricting most human activities currently carried out in the Sundarbans; and that this should be accompanied by good-quality research, particularly to identify the causes of top-dying.

\section{Overview of Findings from the Questionnaire Survey}

Although it is often difficult to pick out one predominant thread from the range of comments made by the respondants to this questionnaire, it is clear that top-dying is a very prevalent problem which respondants were familiar with and believed to be getting worse; that this led to the view that the Sundarbans was not currently in a healthy state; and its regeneration of trees was getting worse. The fact that several different reasons were cited as possible causes of top-dying and the lack of a clear starting point for the problem, suggest that the true causes are likely to be varied and gradual in their effects, and quite possibly several factors interact to lead to the problem. In connection with the causes of top-dying indicated by these local people, and with the indications of health problems and their causes, it must be remembered that these are indications of what people think, but that these perceptions of causes might not be valid; external verification of the causes is required. It is notable; however, that local residents as well as forestry workers were keen to see better management of the Sundarbans, for their benefit as well as of the environment. It is likely that local residents who benefit from the Sundarbans will have recommended sustainable management approaches, but probably were not the people recommending an outright ban on all use of the forests, as a few respondants did.

Table 3.5. Signs of siltation, erosion, salinity and presence of regular inundation in the study areas of Chandpai Range in Sundarbans, Bangladesh.

\begin{tabular}{|c|c|c|c|c|c|}
\hline $\begin{array}{l}\text { Comp. } \\
\text { No. }\end{array}$ & $\begin{array}{l}\text { Plot } \\
\text { No. }\end{array}$ & Presence of Siltation & Presence of Erosion & Presence of Salinity & $\begin{array}{l}\text { Presence of Regular } \\
\text { Inundation }\end{array}$ \\
\hline 26 & 1 & $\sqrt{ }$ & $\sqrt{ }$ & $\sqrt{ }$ (less) & $\sqrt{ }$ \\
\hline 26 & 2 & $\sqrt{ }$ & $\sqrt{ }$ & $\sqrt{ }$ (less) & $\sqrt{ }$ \\
\hline 26 & 3 & $\sqrt{ }$ & $\sqrt{ }$ & $\sqrt{ }$ (less) & $\sqrt{ }$ \\
\hline 28 & 1 & $\sqrt{ }$ & $\sqrt{ }$ & $\sqrt{ }$ (less) & $\sqrt{ }$ \\
\hline 28 & 2 & $\sqrt{ }$ & $\sqrt{ }$ & $\sqrt{ }($ less $)$ & $\sqrt{ }$ \\
\hline 28 & 3 & $\sqrt{ }$ & $\sqrt{ }$ & $\sqrt{ }$ (less) & $\sqrt{ }$ \\
\hline 31 & 1 & $\sqrt{ }$ & $\sqrt{ }$ & $\sqrt{ }$ (greater) & $\sqrt{ }$ \\
\hline 31 & 2 & $\sqrt{ }$ & $\sqrt{ }$ & $\sqrt{ }$ (greater) & $\sqrt{ }$ \\
\hline 31 & 3 & $\sqrt{ }$ & $\sqrt{ }$ & $\sqrt{ }$ (greater) & $\sqrt{ }$ \\
\hline
\end{tabular}

\section{Basic Information on the Sites}

As indicated in section 2.1 while carrying out the field sampling certain observations were made on whether there was any sign of erosion taking place, and of whether there was evidence of siltation happening in the area of the plots. Therefore, field information and data have been recorded and summarized in Table 3.5 to know the exact information about presence of siltation ( deposition of particles of $0.002 \mathrm{~mm}$ to $0.06 \mathrm{~mm}$ size), erosion, salinity 
(determined by taste), and regular inundation (four times in 24 hours; 2 high and 2 low tides) near to each $(20 \times 20 \mathrm{~m})$ plot. Siltation, all types of erosion, regular tides, and salinity were observed in all plot areas (and more generally in Sundarbans), but salinity intensity was somewhat greater in compartment 31 areas where top-dying affected trees were scanty. This information is indicated in Table 3.5.

Overall, these results indicate that the normal processes found in mangroves are occurring in the Sundarbans, but the presence of erosion and salinity variation (as well as the moisture content data presented later) suggest that there are problems associated with water flow patterns.

\section{Discussion}

Trees are felled so as to make small pocket clearings so that it is not noticed. However, the aerial view shows there are many such clearing, Our research them has covered almost one third of the Sundarbans and came across several of them (The Daily Star; September 14, 2013).

Human encroachment on the world's largest mangrove forest has particularly increased after the cyclones Sider and Alia which left many coastal villages economically dry. One would not misses the evidence of regular destruction of the forest. Villages are shallowly creeping up on the edges of the forest every year, and who are gradually proceeding inwards (The Daily Star; September 14, 2013).

\subsection{Overview of the Evidence from the Data}

In trying to assess which factors might be responsible for the problem of top-dying, particularly of Heritiera fomes trees, in the Sundarbans, the work described in this outstanding and un-solved research has essentially had four components. These were, firstly, a review of the hypotheses of possible causes and the evidence available on each of them. Secondly, local people were questioned in order to find their views on the state of the problem, and to see what they thought was causing it. Thirdly, data on the vegetation composition, structure and regeneration was obtained, in order to assess what the current situation is in the study areas. Finally, particular emphasis has been placed on analysing soil and water samples from the study sites to determine what chemical elements were present, and their concentrations, so that the relationships between these chemical constituents and the severity of top-dying could be explored. This chapter aims to bring these various themes together, to assess what the results obtained have indicated about the possible causes of top-dying, and then to indicate further work that appears necessary arising from these conclusions. The survey of the opinions of local people proved to be less satisfactory than had been hoped. In part, this was because several people were often involved at one time as part of a group, and there was very clear evidence of a point becoming established as a group opinion once it had been made, without any dissention by other members of the group. Also, the range of views as to the causes of top-dying varied greatly from group to group, presumably reflecting the particular prejudices or local circumstances affecting the people in that area. Consequently, it was very difficult to conclude anything substantive as to the possible causes from this line of evidence. One point that all respondents did agree on, however, was that the scale of the problem was getting worse over time, emphasising the importance and urgency of trying to find out the causal factor(s) so that the problem might be alleviated. As mentioned in section in Figure 3.1, it is also likely that the top-dying has been getting worse gradually rather than with an abrupt particular starting point in time.

The evidence presented in this thesis therefore points not to one specific factor as being entirely responsible for the increasing amount of top-dying, but rather to a combination of factors; changing water supply and heavy metal contamination in particular, coupled with possible $\mathrm{pH}$ changes, lead to a weakening of the trees, which are then more susceptible to greater attack by pathogens and lowered resistance to them by the trees. This combination of factors is also supported by the comments of the people interviewed, who suggested many different factors as the cause as well as implying that the change was gradual by not being able to pick out a specific starting date to the problem. This would be precisely the pattern that might be expected where no one factor was solely responsible, and the combinations of factors might be somewhat different in different areas. Of course, having a number of interlinked factors as believed likely causes of the problem makes a solution to the problem more difficult. Some suggestions are analysed in this avid research for ways of alleviating the problems, as well as further valuable research to save the largest single tracts of mangroves in the world.

\section{Conclusion}

Although there were only a few individual chemical elements which showed significant correlations with the amount of top-dying, there was evidence of elevated heavy-metal concentrations of many elements in the Sundarbans, which are likely to contribute to the increase in top-dying observed. There were also significant differences between different areas in the Sundarbans, and evidence of water supply problems to the system. Therefore, it is concluded that several factors are responsible for this increase in top-dying, rather than one specific factor only.

\section{Acknowledgements}

Since, Dr. Mohd. Abdul Awal's research work was supported financially by the Peoples' Republic of Bangladesh and the Asian Development Bank (ADB), whom I thank. Particular thanks are due to the ADB head office, Manila for their support and help. I thank sincerely Dr. W.G.H. Hale (my Principal Supervisor), University of 
Bradford, UK, Professor Mike Ashmore (my Technical Supervisor), University of York, UK and Dr. P.J. Hogarth for their advice and comments on the work; Dr. Ben Stern(my ICPMS adviser) and the staff at the Analytical Centre, Bradford, for their help with the ICPMS analyses; Professor Sirajul Hoque, and staff at Dhaka University for providing facilities; and staff of the Forestry Service, Bangladesh Government, for field assistance. Moreover I indebted to my beloved parents (Munshi Aowlad Hossain, Mrs. Ashrafunness), Dr. Shahanaj Khatun (my wife), Munshi Tasneem Redowan (my son), Marwa Ashra (my daughter), Munshi Abul Kalam Azad ( my brother), Abdus Salam (my brother) and my six sister (Laila Anjumand banu, Akter Roshida banu, Saleha Parvin, Azmeri Ferdouwsi, Jannatul Ferdousi and Bedowra Ferdouwsi) and other family members for their inspiration and help for this invaluable research in one of most remote place in the world (Sundarbans), Bangladesh.

\section{References}

[1] ADB, 1992. Non-Wood forests Products. Project 372001/9; forest master Plan, Bangladesh. Asian development Bank, Manila, Philippines: 46-50.

[2] Asian Development Bank, 1993-95. Main Plan-1993/2012. Vol.1. Forestry Master Plan. Asian Development Bank, Manila, Philippines.

[3] Alam, M. K. 1990. Comments of top dying of Sundri trees. In: Rahman, M. A; Khandakar, K; Ahmed, F. U. and Ali, M.O. (eds). Proceedings of the seminar on top-dying of Sundri (Heritiera fomes) trees. Bangladesh Agricultural Research Council, Dhaka, Bangladesh, p.90.

[4] Awal, M.A. (2007). Analysis of possible environmental factors causing top-dying in mangrove forest trees in the Sundarbans in Bangladesh. PhD thesis, University of Bradford;p:1-170.

[5] Awal, M.A., Hale, W.H.G. \& Stern, B. (2009). Trace element concentrations in mangrove sediments in the Sundarbans, Bangladesh. Marine Pollution Bulletin, 58(12), 1944-1948.

[6] Awal, M.A. (2014). "Correlation between the chemical composition of the surface sediment and water in the mangrove forest of the Sundarbans, Bangladesh, and the regeneration, growth and dieback of the forest trees and people health"..Journal of Science Innovation; 2014. 2(2): pp.11-21.Science Publishing Group, USA; May 20th, 2014(2):11-21;doi: 10.11648/j/si.20140202.11.

[7] Bakshi, B. K. 1954. Wilt disease of Dalbergia sissoo Roxb due to Fusarium solani Sensu Snyder and Hensen. Natural Nature 174: 278-291.

[8] Bangladesh Bureau of Statistics, 2006. Statistical Yearbook of Bangladesh, Statistics Division. Ministry of Planning. Dhaka, Bangladesh.

[9] Bangash, S. H; Gardiner, B. N. 1985. Dieback disease - a cause of boron deficiency in forest trees. The Pakistan Journal of Forestry, 35: 21-29.
[10] Blanquet, J. B. 1932. Plant Sociology: the study of plant communities. Edited and translated by G.D. Fuller and H.S. Conard, New York.

[11] Blasco, F. 1975. Mangroves in India. French Institute of Pondicherry. Trav. 14: 1-80.

[12] Blasco, F. (1977). Outlines of Ecology, Botany and Forestry of the Mangals of the Indian sub-continent. In: Wet coastal ecosystem (ed. V.J. Chapman), Elsevier, Amsterdam 13(1), 19(2).

[13] Chaffey, D. R; Miller, F.R; Sandom, J. H. 1985. A forest inventory of the Sundarbans, Bangladesh, Main report, Project Report No.140, 196 pp; Overseas Development Administration, London, U.K:195-196.

[14] FAO / UNEP, 1981. Food loss Prevention in Perishable Crops. FAO Agricultural Services Bull, 43, Italy, Rome.

[15] FAO, 1982. Management and utilization of mangroves in Asia and the Pacific.1982. FAO Environment Paper, 3.Rome:160-168.

[16] FAO / UN, 1984. Integrated Development of the Sundarbans, Bangladesh. Fisheries Integrated Development in the Sundarbans. UNDP/FAO Project BGD/81/035, Rome.

[17] FAO, 1993. Forest resources assessment 1990: Tropical countries. FAO Forestry Paper. 112, Rome, 98-102p.

[18] FAO, 1994. Review of the state of world marine fisheries resources. FAO Fisheries resources. FAO Fisheries Technical Approach Paper 335:143.

[19] FAO, 1997. State of the World's Forests. Food and Agriculture Organization of the United Nations. Rome, Italy.

[20] FAO, 1996. Deforestation status of the World's Forests. Food and Agriculture Organization of the United Nations. Rome, Italy.

[21] Government of Republic of Bangladesh, 1985. The draft of (1985-90) 5th five year plan, Dhaka, Bangladesh.

[22] Government of Bangladesh, (1993). Forestry Master Plan: Executive Summary. Asian Development Bank, UNDP/FAOBGD/88/025, Forest Department, Government of Bangladesh, Dhaka.31p.

[23] Government of India, 1990. Conservation of Mangroves in India, Ministry of Environment and Forests, New Delhi, August, 1990.

[24] Government of Maldives (1994), State of the Environment Maldives 1994, Ministry of planning Human Resources and Environment, Male, Republic of Maldives.

[25] Government of Republic of Korea (1994). Ministry of Environment 1994, Environmental Protection in Korea to UNCED, Ministry of Environment. Seoul.

[26] Government of Republic of Thailand, 1981. Ecological Studies for Conservation of Shore Birds in Songkhla lake, 1:559, Bangkok.

[27] Jimenez, J. A; Cintron, and G. Lugo, A.E. (1985). Tree mortality in mangrove forests. Biotropica 17(3): 177-185.

[28] Jimenez, C. Y. 1993. Soil compaction as a constraint to tree growth in tropical and subtropical urban habitats. Environmental Conservation. 20: 35-49. 
[29] Miranda, L. B; Castro, B. M; Kjerfve, B.1998. Circulation and mixing due to tidal forcing in Bertioga channel, $S$ a0 paulo, Brazil Estuaries, 21 (2): 204-214.

[30] Naskar, K. and Mandal, R. 1999. Ecology and Biodiversity of Indian Mangroves, Publishing House, New Delhi, India, Volume, I \& II, p.21.

[31] Prain, D. 1903. Flora of the Sundarban. Records of the Botanical Survey of India. Periodical Expert Book Agency, Delhi.pp.231-370.

[32] Rahman, M.A. 2000-2001. Diseases and disorders of tree species in the Sundarbans and their management. In: Siddiqi, N.A. and Baksa, M.W.(eds.). Mangrove research and Development, Bangladesh Forest Research institute, Chittagong: 1986-1997, 3(1 and 2):86-93.

[33] Rahman, M.A. 2003. Mid-term Report on Top Dying of Sundri (Heritiera fomes) and Its Management in the Sundarbans Biodiversity Conservation Project, Khulna.109pp.
[34] Thom, B.G.1982. Mangrove ecology- a geo-morphological perspective. 1982, p.3-17.

[35] Tiner, R. W; J R. (1984). Wetlands of the United States: Current Status and Recent Trends. Newton Corner, Massachusetts: U.S. Fish and Wildlife Service, Habitat Resources.

[36] The Daily Star, September 14, 2013.Status of Sundarbans in Bangladesh.

[37] UN-ESCAP, 1987. Final Report: Volume 2. Coastal environment management plan for Bangladesh. Bangkok, Thailand.

[38] UN-ESCAP, 1988. Coastal environment management plan for Bangladesh. Bangkok, Thailand: 7-34.

[39] UNESCO, 1997. Convention Concerning the Protection of the World Cultural and Natural Heritage, France, Paris.

[40] WFB, 2006. The world fact book-Bangladesh. Population of Bangladesh, Wild Fact Book: 2-3. 